\title{
Expression of SMAD proteins, TGF-beta/activin signaling mediators, in human thyroid tissues
}

\author{
Expressão de proteínas SMAD, mediadores da sinalização \\ de TGF-beta/activina, em tecidos de tiroide humana
}

Sílvia E. Matsuo', Ana Paula Z. P. Fiore', Simone M. Siguematu', Kátia N. Ebina', Celso U. M. Friguglietti', Maria C. Ferro ${ }^{2}$, Marco A. V. Kulcsar ${ }^{1,3}$, Edna T. Kimura'

1 Departamento de Biologia Celular e do Desenvolvimento, Instituto de Ciências Biomédicas, Universidade de São Paulo (ICBUSP), São Paulo, SP, Brazil ${ }^{2}$ Departamento de Morfologia e Patologia, Pontifícia Universidade Católica (PUC), Sorocaba, SP, Brazil ${ }^{3}$ Departamento de Cirurgia de Cabeça e Pescoço, USP, São Paulo, SP, Brazil

\author{
Correspondence to: \\ Edna T. Kimura \\ Departamento de Biologia Celular \\ e do Desenvolvimento, \\ Instituto de Ciências Biomédicas, \\ Universidade de São Paulo \\ Av. Prof. Lineu Prestes, 1524 \\ 05508-000 - São Paulo, SP, Brazil \\ etkimura@usp.br
}

Received on Nov/7/2009

Accepted on Feb/24/2010

\begin{abstract}
Objective: To investigate the expression of SMAD proteins in human thyroid tissues since the inactivation of TGF- $\beta$ /activin signaling components is reported in several types of cancer. Phosphorylated SMAD 2 and SMAD3 (pSMAD2/3) associated with the SMAD4 induce the signal transduction generated by TGF- $\beta$ and activin, while SMAD7 inhibits this intracellular signaling. Although TGF- $\beta$ and activin exert antiproliferative roles in thyroid follicular cells, thyroid tumors express high levels of these proteins. Materials and methods: The protein expression of SMADs was evaluated in multinodular goiter, follicular adenoma, papillary and follicular carcinomas by immunohistochemistry. Results: The expression of pSMAD2/3, SMAD4 and SMAD7 was observed in both benign and malignant thyroid tumors. Although pSMAD2/3, SMAD4 and SMAD7 exhibited high cytoplasmic staining in carcinomas, the nuclear staining of pSMAD2/3 was not different between benign and malignant lesions. Conclusions: The finding of SMADs expression in thyroid cells and the presence of pSMAD2/3 and SMAD4 proteins in the nucleus of tumor cells indicates propagation of TGF- $\beta$ /activin signaling. However, the high expression of the inhibitory SMAD7, mostly in malignant tumors, could contribute to the attenuation of the SMADs antiproliferative signaling in thyroid carcinomas. Arq Bras Endocrinol Metab. 2010;54(4):406-12

Keywords

SMAD2/3; SMAD4; SMAD7; thyroid cancer; TGF- $\beta$; activin
\end{abstract}

\section{RESUMO}

Objetivo: Investigar a expressão de proteínas SMAD em tecidos de tiroide humana desde que a inativação dos componentes da sinalização de TGF- $\beta$ /activina é relatada em diversos tipos de câncer. SMAD 2 e SMAD3 fosforilados (pSMAD2/3) associados com SMAD4 induzem a transmissão do sinal gerado por TGF- $\beta$ e activina, enquanto SMAD7 inibe essa sinalização intracelular. Embora TGF- $\beta$ e activina exerçam efeitos antiproliferativos nas células foliculares da tiroide, tumores de tiroide expressam altos níveis dessas proteínas. Materiais e métodos: A expressão proteica de SMADs foi avaliada em bócio multinodular, adenoma folicular, carcinomas papilífero e folicular por imuno-histoquímica. Resultados: A expressão de pSMAD2/3, SMAD4 e SMAD7 foi observada tanto em tumores benignos como malignos da tiroide. Embora pSMAD2/3, SMAD4 e SMAD7 exibissem alta positividade citoplasmática em carcinomas, a positividade nuclear de pSMAD2/3 não foi diferente entre lesões benignas e malignas da tiroide. Conclusões: 0 achado da expressão de SMADs em células tiroidianas e a presença das proteínas pSMAD2/3 e SMAD4 no núcleo de células tumorais indicam propagação da sinalizaçãoTGF- $\beta$ /activina. Contudo, a alta expressão de SMAD7 inibitório, principalmente em tumores malignos, poderia contribuir para atenuação da sinalização antiproliferativa de SMADs em carcinomas de tiroide. Arq Bras Endocrinol Metab. 2010;54(4):406-12

Descritores

SMAD2/3; SMAD4; SMAD7; câncer de tiroide; TGF- $\beta$, activina 


\section{INTRODUCTION}

$\mathrm{T}$ hyroid tumors are the most common neoplasms of the endocrine system (1). They are classified as benign tumors (adenomas and multinodular goiters) and malignant tumors, which are allocated as differentiated (papillary and follicular carcinomas) and poorly differentiated (anaplastic carcinoma) (1). The thyroid malignant transformation is dependent on molecular alterations that result in a disruption of several intracellular signaling, including the unbalance of TGF- $\beta$ / activin inhibitory pathway, by a mechanism not yet clarified $(2,3)$.

The TGF- $\beta$ superfamily is comprised of related proteins including the TGF- $\beta$ s, activins and bone morphogenetic proteins which affect a wide variety of biological processes, regulating cell proliferation and differentiation, apoptosis and development $(4,5)$. TGF- $\beta$ acts by binding to specific serine/threonine kinase transmembrane receptors, which induce intracellular signaling mediated by SMAD proteins. The receptors complexed to TGF- $\beta$ phosphorylate and activate the receptor-regulated SMADs (R-SMAD), SMAD2 and SMAD3. The activation of SMAD2/ SMAD3 allows their interaction with common-mediator SMAD (Co-SMAD), SMAD4, and then this complex moves to the nucleus where it regulates gene transcription. Although activin binds to its own specific receptors, the same set of SMADs is recruited for its signal transduction (6-10). This TGF- $\beta$ /activin signaling is attenuated by SMAD7, an inhibitory SMAD (I-SMAD) that prevents phosphorylation of SMAD2 $/ 3$ and interferes with the formation of complex SMAD2/3 and SMAD4 $(11,12)$.

TGF- $\beta$ and activin are proliferation-inhibitory factors for epithelial cells, such as hepatic, intestinal, mammary, pancreatic and prostatic cells including thyroid follicular cells (13-19). Although both TGF- $\beta$ and activin exert inhibitory effects on the proliferation of normal thyroid follicular cells, we have previously reported that thyroid tumors express the TGF- $\beta$ isoforms, TGF $\beta-1$, TGF $\beta-2$ and TGF $\beta-3$ as well as activin isoforms, activin A and activin B (20,21). An impairment of signal transduction has been identified in the development and progression of several epithelial cancers $(17,22)$. Therefore, in this study, we investigated the integrity of TGF- $\beta$ /activin signaling by analyzing the expression of SMAD2/3, SMAD4 and SMAD7 proteins in thyroid tumors.

\section{MATERIALS AND METHODS}

We analyzed the expression of SMAD4, phosphorylated SMAD2/3 and SMAD7, in normal and tumoral thyroid tissue by immunohistochemical method.

Paraffin sections from human thyroid of normal tissue $(\mathrm{N}, \mathrm{n}=12)$, multinodular goiter $(\mathrm{MNG}, \mathrm{n}=10)$, follicular adenoma $(\mathrm{FA}, \mathrm{n}=5)$, follicular carcinoma $(\mathrm{FC}, \mathrm{n}=4)$ and papillary carcinoma ( $\mathrm{PC}, \mathrm{n}=9$ ), were submitted to deparaffinization in xylene and hydration through a series of decreasing alcohol concentrations. The immunohistochemical procedure was performed by an indirect 3 -stage immunoenzymatic method as described previously (23). Briefly, after endogenous peroxidase activity was blocked with $3 \%$ hydrogen peroxide for 15 minutes, tissues were washed in phosphate-buffered saline (PBS) and were incubated with goat polyclonal anti-phosphorylated SMAD2/3 antibody (sc-11769, Santa Cruz Biotechnology, Santa Cruz, CA) or rabbit polyclonal anti-SMAD4 (sc-7154, Santa Cruz Biotechnology) or goat polyclonal anti-SMAD7 antibody (sc-7004, Santa Cruz Biotechnology) overnight. The primary antibodies were diluted at 1:100 in Tris-buffered saline and $0.05 \%$ albumin. Between the antibodies incubation the tissues were washed in PBS. After incubation with biotin-streptavidin-peroxidase, the reaction was revealed by a mixture of 3,3 '-diaminobenzidine with hydrogen peroxide. The sections were then counterstained with Gill's hematoxylin. The immunopositivity of the reaction was detected as brown staining observed by light microscopy. The intensity of immunostaining of follicular cells was evaluated and classified as weak, moderate and strong. Due to variable intensity of positivity seen even in the same tissue, we considered the staining intensity present in more than $50 \%$ of positive cells. The percentage of $\mathrm{pSMAD} 2 / 3$ immunopositive cells was determined by counting 3 areas randomly chosen in the tissue in a total of 900 cells. The percentage of nuclear stained cells for pS$\mathrm{MAD} 2 / 3$ was also determined.

The negative control was performed omitting the primary antibody (SMAD4) and incubating tissues with primary antibody preabsorbed with corresponding peptide, pSMAD2/3 (sc-11769 P, Santa Cruz Biotechnology) and SMAD7 (sc-7004 P, Santa Cruz Biotechnology) peptides (antibody/peptide: 1/5) overnight.

The statistical analysis was made using the semiquantitative results of immunohistochemical staining. The data are presented as the mean \pm standard deviation (SD) and were submitted to analysis of variance 
followed by the Student Newman-Keuls test to compare results between samples. Differences were considered significant at $\mathrm{P}<0.05$.

This study was approved by the Ethical Committee for Human Research of the Biomedical Sciences Institute, University of Sao Paulo, Brazil.

\section{RESULTS}

The expression pattern of SMADs in the neoplastic cells of papillary carcinoma was predominantly homogeneous and strong. In MNG, heterogeneous positivity of SMADs was observed in the same tissue with a given follicle displaying positive and negative cells. Phosphorylated SMAD2/3 was detected in all tissues, however its expression is stronger in carcinomas (follicular and papillary) (Figure 1). The analysis of immunohistochemical staining in the normal and neoplastic tissues is summarized in table 1 .

To further investigate the integrity of SMAD signaling in thyroid tumors, we evaluated the percentage of pSMAD2 $/ 3$ positive cells and the localization of this protein at the subcellular level in thyroid tumor tissues (Figure 2A). The immunohistochemical analysis of pSMAD2 $/ 3$ expression showed that the number of positive cells for pSMAD2 $/ 3$ was higher in tumoral samples when compared with normal tissue (Figure 2B). Immunopositive cells were more abundant in carcinomas and adenomas than in MNG tissues $(\mathrm{P}<0.05)$. When we analyzed the nuclear staining of $\mathrm{pSMAD} 2 / 3$, positivity was about $30 \%$ and was similar in MNG, adenoma and carcinoma tissues (Figure 2B). We also detected nuclear positivity of SMAD4 in both benign and malig- nant lesions, whereas the immunostaining of SMAD7 was predominantly cytoplasmic.

\section{DISCUSSION}

TGF- $\beta$ and activin exert antiproliferative effects in epithelial cells, including follicular thyroid cells (24). However, TGF- $\beta$ and activin are overexpressed in several carcinomas $(17,19,25)$. Similarly, we have previously shown high TGF- $\beta$ and activin protein expression in thyroid cancer, while the expression in normal tissue is predominantly negative $(20,21)$. Despite the increased expression of these proteins in neoplastic cells, loss of TGF- $\beta$ /activin responsiveness is frequently observed in cancer (2). In human goiter samples, proliferation was not inhibited in the presence of TGF- $\beta$ (26), proving that even cells derived from benign lesions became irresponsive to TGF- $\beta$. Conversely, we have shown that a papillary thyroid carcinoma cell line is still sensitive to the antiproliferative effect generated distinctly by TGF- $\beta 1$ and activin, possibly mediated by a functional Smad pathway (27). SMAD2, SMAD3 and SMAD4 are TGF- $\beta$ /activin intracellular mediators, representing the stimulatory SMADs of this signaling pathway, while SMAD7 is an inhibitory SMAD for this pathway (6-8). In the present study, to verify the integrity of the SMAD pathway, we investigated the expression of SMAD4, pSMAD2/3 and SMAD7 in thyroid tumors. As illustrated in figure 2, SMAD4 and $\mathrm{pSMAD} 2 / 3$ as well as inhibitory SMAD7 are expressed in all of tumoral stages of thyroid from benign to malignant lesions, whereas these proteins are rarely detected in normal thyroid tissue. SMAD proteins mediate antiproliferative

Table 1. Immunohistochemical analysis of SMAD4, pSMAD2/3 and SMAD7

\begin{tabular}{|c|c|c|c|c|c|c|c|c|c|c|c|c|c|}
\hline & & \multicolumn{4}{|c|}{ SMAD4 } & \multicolumn{4}{|c|}{ pSMAD2/3 } & \multicolumn{4}{|c|}{ SMAD7 } \\
\hline & & - & + & ++ & +++ & - & + & ++ & +++ & - & + & ++ & +++ \\
\hline \multirow[t]{2}{*}{ Normal $(n=12)$} & $\mathrm{N}$ & 9 & 3 & & & 3 & 9 & & & 7 & 3 & 2 & \\
\hline & $\%$ & 75 & 25 & & & 25 & 75 & & & 58 & 25 & 17 & \\
\hline \multirow[t]{2}{*}{ MNG $(n=10)$} & $\mathrm{N}$ & 2 & 8 & & & & 6 & 2 & 2 & & 8 & 2 & \\
\hline & $\%$ & 20 & 80 & & & & 60 & 20 & 20 & & 80 & 20 & \\
\hline \multirow[t]{2}{*}{$\mathrm{FA}(\mathrm{n}=5)$} & $\mathrm{N}$ & 2 & 2 & 1 & & & 2 & & 3 & 1 & 3 & & 1 \\
\hline & $\%$ & 40 & 40 & 20 & & & 40 & & 60 & 20 & 60 & & 20 \\
\hline \multirow[t]{2}{*}{$\mathrm{FC}(\mathrm{n}=4)$} & $\mathrm{N}$ & 1 & & & 3 & & & 1 & 3 & & & 1 & 3 \\
\hline & $\%$ & 25 & & & 75 & & & 25 & 75 & & & 25 & 75 \\
\hline \multirow[t]{2}{*}{$P C(n=9)$} & $\mathrm{N}$ & & 3 & 2 & 4 & & & 1 & 8 & & 2 & 4 & 3 \\
\hline & $\%$ & & 33 & 22 & 45 & & & 11 & 89 & & 22 & 45 & 33 \\
\hline
\end{tabular}

Intensity: negative (-), weak (+), moderate $(++)$, strong (+++) 
pSMAD2/3

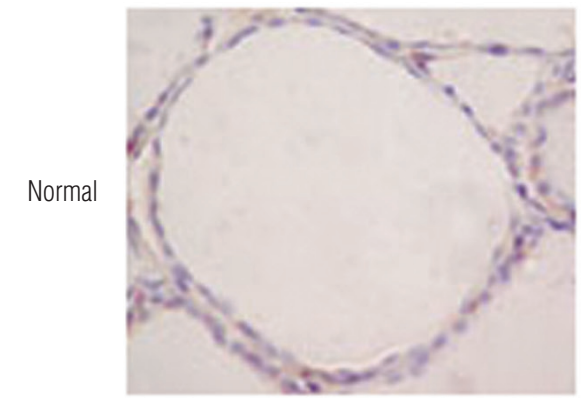

MNG
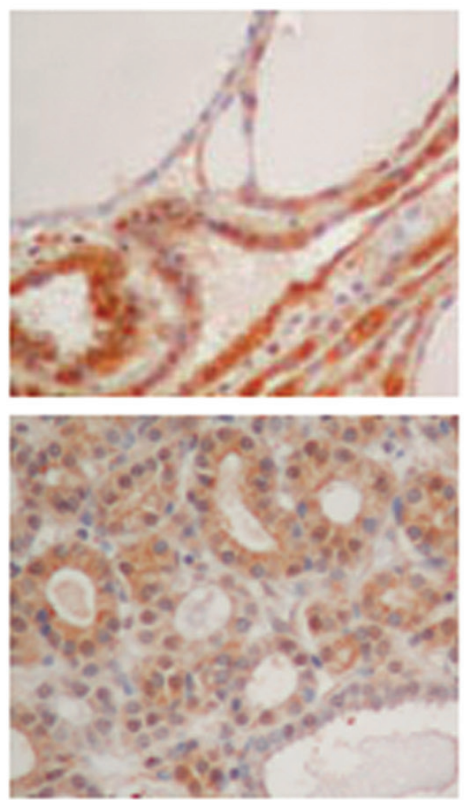

Follicular

adenona

Papillary

carcinoma

Follicular

carcinoma
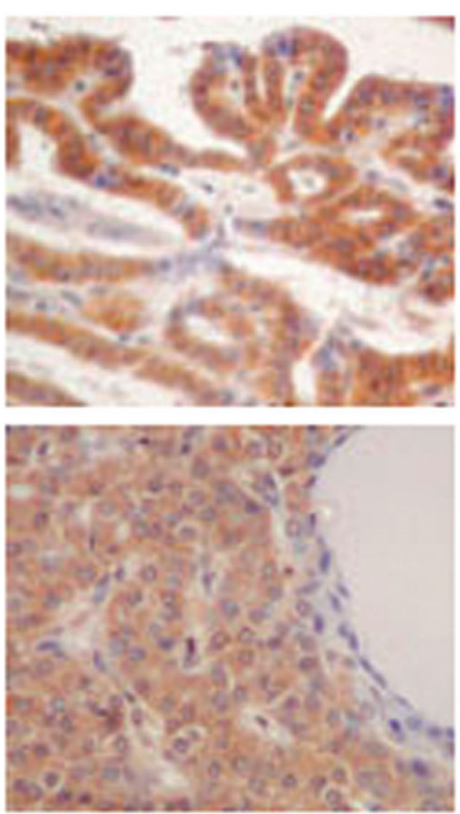

SMAD4
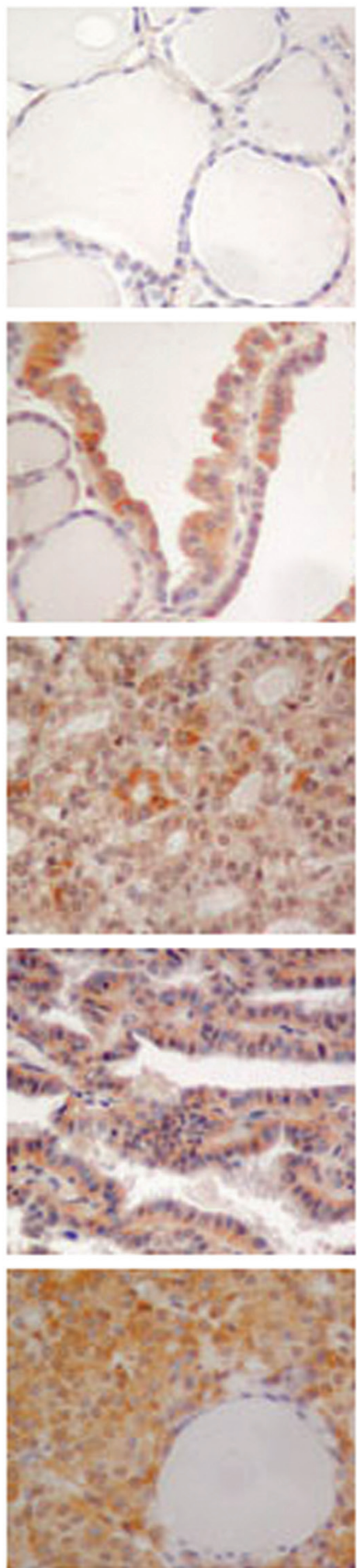

SMAD7
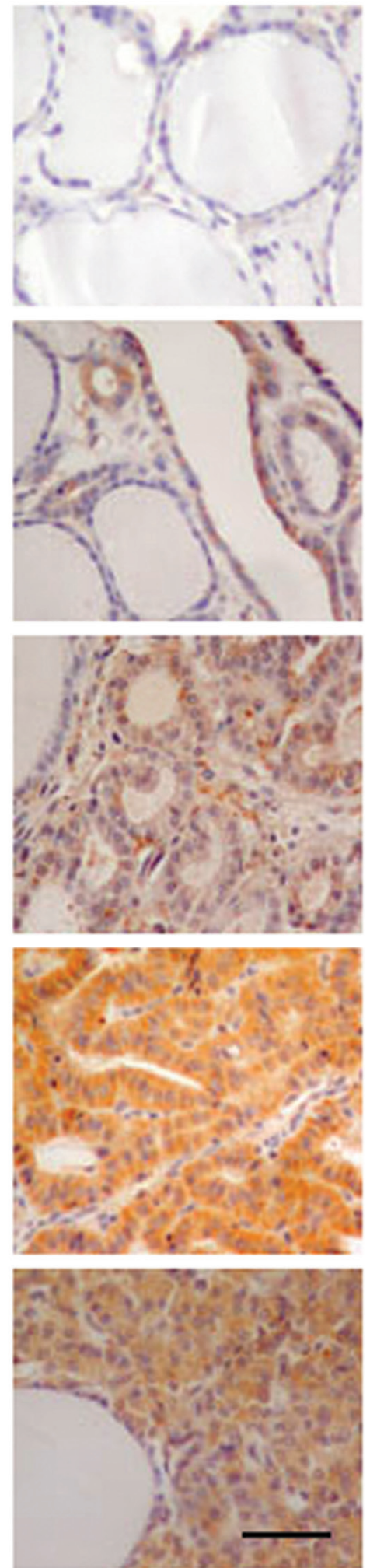

Figure 1. Immunohistochemical staining for pSMAD2/3, SMAD4 and SMAD7 in human thyroid tumors by the peroxidase method. The positivity of immunoreaction is shown by brown staining in representative sections from normal tissue, multinodular goiter (MNG), follicular adenoma, papillary carcinoma and follicular carcinoma. Nuclei were counterstained with hematoxylin, which appear in blue. Bar $=50 \mu \mathrm{m}$. 
A

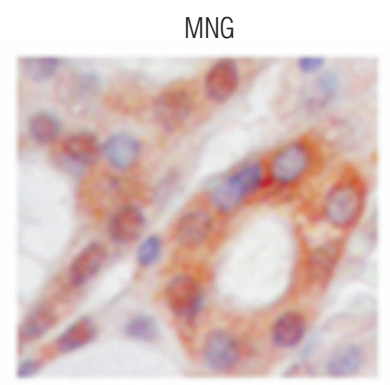

FA

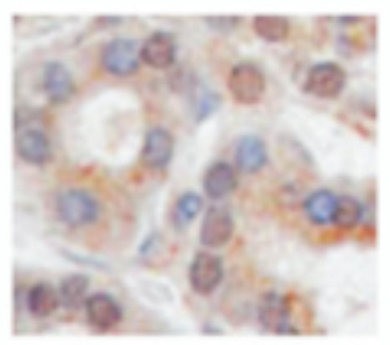

FC

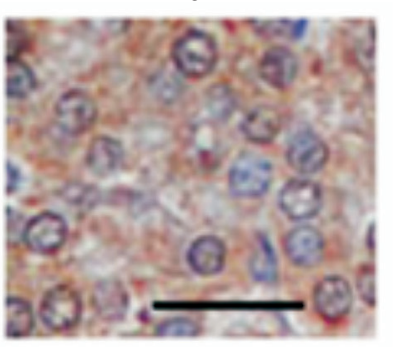

PC

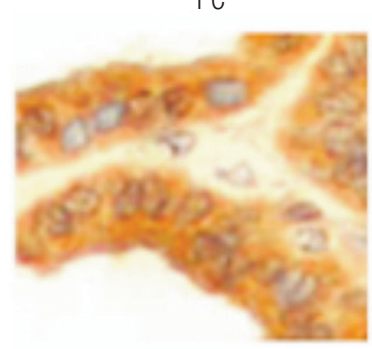

B

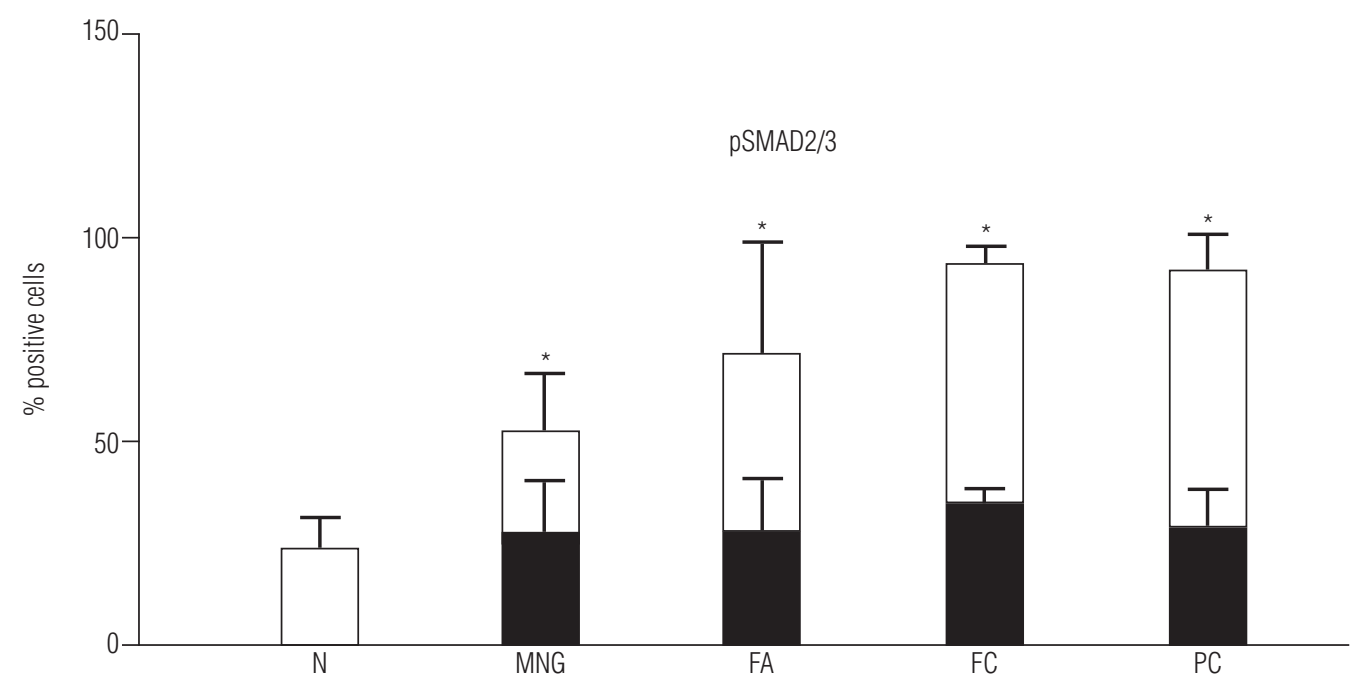

Figure 2. Immunohistochemical analysis of pSMAD2/3 expression in thyroid tumors. (A) Immunohistochemical localization of pSMAD2/3 in multinodular goiter (MNG), follicular adenoma (FA), follicular carcinoma (FC), papillary carcinoma (PC). The cytoplasmic and nuclear positivity of follicular cells is shown by brown staining. The sections were counterstained with hematoxylin and negative nuclei for pSMAD2/3 were stained blue. Bar $=25 \mu \mathrm{m}$. (B) Semiquantitative analysis of pSMAD2/3 immunopositivity. The graph shows the percentage of positive cells in normal tissue $(N, n=12), M N G(n=10)$, FA ( $n=5)$, FC $(n=4)$ and $P C(n=9) .{ }^{*} P<0.05 v s$. normal. Black bars in the graph represent the percentage of nuclear positive cells.

effects by inducing the expression of the CDK inhibitors, p15 and p21, and by inhibiting c-MYC expression in several epithelial cell lines responsive to TGF- $\beta$ or activin $(22,28-30)$. The loss of TGF- $\beta$ /activin responsiveness caused by inactivation of the signaling pathway's components, such as deletions or mutations in either TGF- $\beta$ or activin receptors and SMADs, has been identified in the development and progression of a variety of cancers, conferring a potential tumor suppressive role for the SMADs pathway $(2,31,32)$.

Although the number of $\mathrm{pSMAD} 2 / 3$ positive cells was significantly higher in carcinomas (Figure 2B) compared with benign lesion ( $\mathrm{MNG})$, the percentage of nuclear positive cells for pSMAD2/3 expression was not different among tumors (Figure $2 \mathrm{~B}$ ). The presence of pSMAD2/3 in the nucleus of neoplastic cells indicates that the TGF- $\beta /$ receptor or activin/receptor complex is intact and able to activate downstream mediators of the cascade such as SMADs.
SMAD4 is known as DPC4 (deleted in pancreatic carcinoma locus 4 ) due to high frequency of deletions in the gene encoding SMAD4 found in pancreatic carcinoma. Inactivating mutations or deletions of this gene in others cancers such as colon carcinomas and, more recently, in thyroid tumors, were also reported $(28,33)$. Differently from what is observed in pancreatic and colon carcinomas, in our study, SMAD4 was expressed in most thyroid tumors, displaying high expression mainly in the carcinomas.

SMAD7 inhibits the growth arrest and apoptosis induced by TGF- $\beta$ and activin $(34,35)$. The transcription of SMAD7 is induced by either TGF- $\beta$ or activin representing a negative feedback mechanism of TGF- $\beta$ / activin signaling (36). Unlike SMAD2, SMAD3 and SMAD4, display nuclear translocation induced upon ligand stimulus, SMAD7 accumulates in the cytoplasm upon TGF- $\beta /$ receptor activation to inhibit signal transduction (37). Up-regulation of SMAD7 is reported in 
several carcinomas and is implicated in cancer progression (38-40). In thyroid tumor, we detected increased expression of inhibitory SMAD7 in papillary and follicular carcinomas, indicating that SMAD7 may be also involved in thyroid tumorigenesis.

In this study, the presence of nuclear immunopositivity for the stimulatory SMADs, SMAD4 and pS$\mathrm{MAD} 2 / 3$ indicates that the TGF- $\beta$ /activin signaling pathway is intact in thyroid tumors. This antiproliferative signaling is critical to limit tumor progression. However, the antiproliferative SMADs signal induced by TGF- $\beta$ /activin proteins could be attenuated by the high expression of an antagonist SMAD, SMAD7, observed mostly in thyroid carcinomas.

Acknowledgments: we are grateful to Dr. Alison Colquhoun for critical review of the manuscript. This study was supported by research grants from the Sao Paulo State Research Foundation (Fapesp), Coordination for the Improvement of Higher Education Personnel (Capes) and National Counsel of Technological and Scientific Development $(\mathrm{CNPq})$ and by Fapesp fellowship grants to SEM, APZPF and to KNE, Capes fellowship grants to APZPF and CNPq fellowship grants to SMS. ETK is a CNPq-funded investigator.

Disclosure: no potential conflict of interest relevant to this article was reported.

\section{REFERENCES}

1. DeLellis RA, Lloyd RV, Heitz PU, Eng C. WHO Classification of tumours. pathology and genetics of tumours of endocrine organs. Lyon: IARC Press; 2004.

2. Derynck R, Akhurst RJ, Balmain A.TGF-beta signaling in tumor suppression and cancer progression. Nat Genet. 2001;29(2):117-29.

3. Massague J, Blain SW, Lo RS. TGFbeta signaling in growth control, cancer, and heritable disorders. Cell. 2000;103(2):295-309.

4. Derynck R, Feng XH. TGF-beta receptor signaling. Biochim Biophys Acta. 1997;1333(2):F105-50.

5. Moustakas A, Souchelnytskyi S, Heldin $\mathrm{CH}$. Smad regulation in TGF-beta signal transduction. J Cell Sci. 2001;114(Pt 24):4359-69.

6. Pangas SA, Woodruff TK. Activin signal transduction pathways. Trends Endocrinol Metab. 2000;11(8):309-14.

7. ten Dijke $\mathrm{P}$, Miyazono $\mathrm{K}$, Heldin $\mathrm{CH}$. Signaling inputs converge on nuclear effectors in TGF-beta signaling. Trends Biochem Sci. 2000;25(2):64-70.

8. Mehra A, Wrana JL. TGF-beta and the Smad signal transduction pathway. Biochem Cell Biol. 2002;80(5):605-22.

9. Shi Y, Massague J. Mechanisms of TGF-beta signaling from cell membrane to the nucleus. Cell. 2003;113(6):685-700.

10. Kimura ET, Matsuo SE, Ricarte-Filho JC. [TGFbeta, activin and SMAD signalling in thyroid cancer]. Arq Bras Endocrinol Metabol. 2007;51(5):683-9.

11. Hayashi H, Abdollah S, QiuY, Cai J, XuYY, Grinnell BW, et al.The MAD-related protein Smad7 associates with the TGFbeta receptor and functions as an antagonist of TGFbeta signaling. Cell. 1997;89(7):1165-73.

12. Lebrun JJ, Takabe K, Chen $Y$, Vale W. Roles of pathway-specific and inhibitory Smads in activin receptor signaling. Mol Endocrinol. 1999;13(1):15-23.
13. Roberts $A B$, Sporn MB. The transforming growth factor- $\beta$ s. In: Sporn MB, Roberts AB, editors. Peptide Growth Factors and Their Receptors I. New York: Springer-Verlag; 1991. p. 418-72.

14. Pang XP, Park M, Hershman JM. Transforming growth factor-beta blocks protein kinase-A-mediated iodide transport and protein kinase-C-mediated DNA synthesis in FRTL- 5 rat thyroid cells. Endocrinology. 1992;131(1):45-50.

15. Taton M, Lamy F, Roger PP, Dumont JE. General inhibition by transforming growth factor beta 1 of thyrotropin and cAMP responses in human thyroid cells in primary culture. Mol Cell Endocrinol. 1993;95(1-2):13-21.

16. Franzen A, Piek E, Westermark B, ten Dijke P, Heldin NE. Expression of transforming growth factor-beta1, activin $A$, and their receptors in thyroid follicle cells: negative regulation of thyrocyte growth and function. Endocrinology. 1999;140(9):4300-10.

17. Gold LI. The role for transforming growth factor-beta (TGF-beta) in human cancer. Crit Rev Oncog. 1999;10(4):303-60.

18. Schulte KM, Jonas C, Krebs R, Roher HD. Activin A and activin receptors in the human thyroid: a link to the female predominance of goiter? Horm Metab Res. 2000;32(10):390-400.

19. Chen YG, Lui HM, Lin SL, Lee JM, Ying SY. Regulation of cell proliferation, apoptosis, and carcinogenesis by activin. Exp Biol Med (Maywood). 2002;227(2):75-87.

20. Kimura ET, Kopp P, Zbaeren J, Asmis LM, Ruchti C, Maciel RM, et al. Expression of transforming growth factor beta1, beta2, and beta3 in multinodular goiters and differentiated thyroid carcinomas: a comparative study. Thyroid. 1999;9(2):119-25.

21. Matsuo SE, Ebina KN, Kulcsar MA, Friguglietti CU, Kimura ET. Activin betaB expression in rat experimental goiter and human thyroid tumors. Thyroid. 2003;13(3):239-47.

22. Siegel PM, Massague J. Cytostatic and apoptotic actions of TGFbeta in homeostasis and cancer. Nat Rev Cancer. 2003;3(11):807-21.

23. Martins L, Matsuo SE, Ebina KN, Kulcsar MA, Friguglietti CU, Kimura ET. Galectin-3 messenger ribonucleic acid and protein are expressed in benign thyroid tumors. J Clin Endocrinol Metab. 2002;87(10):4806-10.

24. Pisarev MA, Thomasz L, Juvenal GJ. Role of transforming growth factor beta in the regulation of thyroid function and growth. Thyroid. 2009;19(8):881-92.

25. La Rosa S, Uccella S, Marchet S, Capella C, Lloyd RV. Localization of inhibins and activins in normal endocrine cells and endocrine tumors of the gut and pancreas: an immunohistochemical and in situ hybridization study. J Histochem Cytochem. 2004;52(2):217-25.

26. Asmis LM, Kaempf J, Von Gruenigen C, Kimura ET, Wagner HE, Studer $\mathrm{H}$. Acquired and naturally occurring resistance of thyroid follicular cells to the growth inhibitory action of transforming growth factor-beta 1 (TGF-beta 1). J Endocrinol. 1996;149(3):485-96.

27. Matsuo SE, Leoni SG, Colquhoun A, Kimura ET. Transforming growth factor-beta1 and activin A generate antiproliferative signaling in thyroid cancer cells. J Endocrinol. 2006;190(1):141-50.

28. Ten Dijke P, Goumans MJ, Itoh F, Itoh S. Regulation of cell proliferation by Smad proteins. J Cell Physiol. 2002;191(1):1-16.

29. Ho J, de Guise C, Kim C, Lemay S, Wang XF, Lebrun JJ. Activin induces hepatocyte cell growth arrest through induction of the cyclin-dependent kinase inhibitor p15INK4B and Sp1. Cell Signal. 2004;16(6):693-701.

30. Burdette JE, Jeruss JS, Kurley SJ, Lee EJ, WoodruffTK. Activin A mediates growth inhibition and cell cycle arrest through Smads in human breast cancer cells. Cancer Res. 2005;65(17):7968-75.

31. Risbridger GP, Schmitt JF, Robertson DM. Activins and inhibins in endocrine and other tumors. Endocr Rev. 2001;22(6):836-58.

32. Su GH, Bansal R, Murphy KM, Montgomery E, Yeo CJ, Hruban RH, et al. ACVR1B (ALK4, activin receptor type 1B) gene mutations in pancreatic carcinoma. Proc Natl Acad Sci U S A. 2001;98(6):3254-7. 
33. Lazzereschi D, Nardi F, Turco A, Ottini L, D'Amico C, MarianiCostantini $R$, et al. A complex pattern of mutations and abnormal splicing of Smad4 is present in thyroid tumours. Oncogene. 2005;24(34):5344-54.

34. Ishisaki A, Yamato K, Nakao A, Nonaka K, Ohguchi M, ten Dijke P, et al. Smad7 is an activin-inducible inhibitor of activin-induced growth arrest and apoptosis in mouse B cells. J Biol Chem. 1998;273(38):24293-6.

35. Halder SK, Beauchamp RD, Datta PK. Smad7 induces tumorigenicity by blocking TGF-beta-induced growth inhibition and apoptosis. Exp Cell Res. 2005;307(1):231-46.

36. Afrakhte M, Moren A, Jossan S, Itoh S, Sampath K, Westermark B, et al. Induction of inhibitory Smad6 and Smad7 mRNA by TGF-beta family members. Biochem Biophys Res Commun. 1998;249(2):505-11.
37. Itoh $\mathrm{S}$, Landstrom $\mathrm{M}$, Hermansson $\mathrm{A}$, Itoh F, Heldin $\mathrm{CH}$, Heldin $\mathrm{NE}$, et al. Transforming growth factor beta1 induces nuclear export of inhibitory Smad7. J Biol Chem. 1998;273(44):29195-201.

38. Boulay JL, Mild G, Lowy A, Reuter J, Lagrange M, Terracciano L, et al. SMAD7 is a prognostic marker in patients with colorectal cancer. Int J Cancer. 2003;104(4):446-9.

39. Dowdy SC, Mariani A, Reinholz MM, Keeney GL, Spelsberg TC, Podratz KC, et al. Overexpression of the TGF-beta antagonist Smad7 in endometrial cancer. Gynecol Oncol. 2005;96(2): 368-73.

40. Liu X, Lee J, Cooley M, Bhogte E, Hartley S, Glick A. Smad7 but not Smad6 cooperates with oncogenic ras to cause malignant conversion in a mouse model for squamous cell carcinoma. Cancer Res. 2003;63(22):7760-8. 